\title{
Figuras femininas e fronteiras sociais na poética de Manoel de Barros
}

\author{
Feminine figures and frontiers social in the \\ poetic of Manoel De Barros
}

Rauer Ribeiro Rodrigues*

\begin{abstract}
Resumo: Refletimos acerca das fronteiras nas relações sociais, verificando de que modo o discurso poético internaliza convenções morais e fixa identidades ao propor a alteridade como um "outro" radicalmente diferente. Estudamos a representação da mulher na poesia de Manoel de Barros, nas figuras da avó, da mãe, das mulheres do povo e das prostitutas. Verificamos o modo como as mulheres são figurativizadas e a função que desempenham no universo poético barreano.
\end{abstract}

Palavras-chave: História, Literatura Brasileira, Poesia

Abstract: We contemplated concerning the borders in the social relationships, verifying that way the speech poetic internalizes the moral conventions and it fastens identities when proposing the alterity as a one "other" radically different. We studied the woman's representation in the poetry of Manoel de Barros, in the grandmother's figures, of the mother, of the women of the people and of the prostitutes. We verified the way as the women are figured and the function that they carry out in the universe of poetic's Barros.

Keywords: History, Brazilian literature, Poetry

O tema da representação da figura feminina tem sido bastante estudado nos últimos anos. Parece-nos que, após o desenvolvimento da História Social e da História das Mentalidades, alguns estudiosos buscaram recuperar personagens históricos até então "invisíveis" aos pesquisadores e, talvez por isso, novas discussões tenham sido

\footnotetext{
* Doutor em Estudos Literários pela UNESP de Araraquara; Professor e pesquisador do Mestrado em Letras da UFMS, Câmpus de Três Lagoas; coordenador do Grupo de Pesquisa Luiz Vilela (http://gpluizvilela.blogspot.com). E-mail: <rauer.rauer@uol.com.br>.

A elaboração deste texto contou com o apoio da pesquisadora Luciene Lemos de Campos. Mestre em Estudos Fronteiriços pela UFMS, Câmpus do Pantanal, em Corumbá. Mestranda em Letras da UFMS, Câmpus de Três Lagoas. E-mail: <lucienelemos10@yahoo.com.br>.
} 
fomentadas acerca dos "papéis" representados pelas mulheres na sociedade, embora ainda sejam relativamente poucos os estudos dedicados só a esse tema.

Nosso propósito, neste estudo, é mostrar como as figuras femininas são representadas na obra de Manoel de Barros. Investigamos a caracterização dos tipos femininos a partir das figuras da mãe, da avó, das prostitutas e das mulheres do povo. Verificamos os papéis destinados a elas, o modo como são caracterizadas pelo poeta e a função que desempenham no universo poético criado por Barros. Como desdobramento dessa leitura da obra de Manoel de Barros, propomos uma reflexão acerca das fronteiras que permeiam as relações sociais, verificando de que modo o discurso poético internaliza convenções morais e fixa identidades ao propor a alteridade como um "outro" radicalmente diferente. Nosso corpus, além de Poemas concebidos sem pecado (1937, doravante PCSP), se volta para as Memórias inventadas: a infância (2003). ${ }^{1}$

Nos poemas de Barros, as personagens femininas ora representam a conduta domiciliar, com a dona de casa cuja virtude está pautada no zelo pela harmonia do lar, ora surgem como mulheres do povo e ora são representadas como prostitutas. Verifiquemos inicialmente a concepção de fronteira que podemos discernir a partir de dois poemas, sintomaticamente nomeados "O muro": o primeiro deles aparece em Face imóvel, cuja primeira edição é de 1942, e o segundo surge em Poemas rupestres, de 2004. Eis esse último:

\section{O MURO}

O menino contou que o muro da casa dele era da altura de duas andorinhas.

(Havia um pomar do outro lado do muro.)

Mas o que intrigava mais a nossa atenção

principal

Era a altura do muro

Que seria de duas andorinhas.

Depois o garoto explicou:

Se o muro tivesse dois metros de altura

qualquer ladrão pulava

Mas a altura de duas andorinhas nenhum ladrão pulava.

Isso era.

(Barros, 2004, p. 59) $)^{2}$

\footnotetext{
1 Também foram lançados, na série Memórias inventadas, os volumes "A segunda infância" (2006), um com o subtítulo "Para crianças" (2007) e "A terceira infância" (2008).

2 Mantivemos nas citações sempre a disposição gráfica, a ortografia e a formatação do original.
} 
Manoel de Barros trata dos vários conceitos de fronteira e insere uma reflexão acerca do espaço social que o outro ocupa. A imagem do muro aparece definida no título do poema, caracterizado pelo determinante "O", o que conota valor qualificativo: "O muro". Não se trata, portanto, de limite qualquer. O sintagma nominal, informado pelo eu-lírico, remete à extremidade de uma casa, um pomar; é o obstáculo com o qual os "ladrões" poderiam se deparar se quisessem entrar no local, mas é também o espaço onde a voz poética se edifica.

No plano da expressão, é informado tanto o imaginado quanto o real. Cada vez mais alto, o muro simboliza não somente um limite marcado, uma proteção, como também o distanciamento, a comunicação interrompida, não efetivada, a impossibilidade ou a probabilidade de interação do eu com os outros. Muitos são os muros construídos com o objetivo de serem barreiras artificiais contra guerras, inimigos, contra bandidos e forasteiros, como também são utilizados para separar, segregar, para esconder tesouros e mazelas.

Usualmente, o termo fronteira é associado à separação, à exclusão do indesejado, de "qualquer ladrão" que, de uma maneira ou outra, ameace o objeto de cobiça em um espaço demarcado. Mais difícil de mensurar a altura do muro quando se insere a imagem da liberdade, conotada pela altura de duas andorinhas - aves migratórias que, para muitos povos, simboliza o indivíduo sem fronteiras, a mobilidade, o migrante, a liberdade e a renovação da vida; "duas andorinhas" remetem a ideia de par, casal, união, solidariedade, conceito oposto ao que o senso comum atribui a muro.

Nesse caso, a fronteira parece representar a possibilidade de congregação e não de efetivação de diferenças: duas andorinhas compõem a pluralização da liberdade, a medida dessa fronteira. Daí "a altura de duas andorinhas" subverter o conceito de limite demarcado com que se tem associado a marca fronteiriça representada pelo muro. Assim, no poema, o conceito de fronteira é paradoxal: o muro separa o espaço da propriedade, mas - inusitada - também une os diferentes. Desse modo, tem-se uma extremidade in-conformada com a principal concepção vigente.

As considerações teóricas de Raffestin corroboram nosso raciocínio:

A ordem e a desordem não são, paradoxalmente, noções opostas e não representam mais do que momentos de um processo semelhante ao da cinemática da fronteira. A fronteira não é uma linha, a fronteira é um dos elementos da comunicação biossocial que assume função reguladora. Ela é a expressão de um equilíbrio dinâmico que não se encontra somente no sistema territorial, mas em todos os sistemas biossociais. (Raffestin, 2005, p. 13). 
Em Barros, o recorte de natureza horizontal, espaço que separa dois povos, torna-se transponível para os indivíduos cuja mobilidade não se limita às certezas pré-concebidas. Já a andorinha, por toda parte, está associada à fertilidade, equilíbrio, alternância de ciclos; é ser que vive em bando na fronteira entre céu e terra. Se faz muito frio ou calor, as andorinhas mudam de moradia.

Muros que protegem ou separam, de certa forma, asseguram ou tentam compor uma identidade, que, no entanto, já surge em diluição. No poema de Barros, percebe-se, o marco fronteiriço é mais abstrato que concreto; a capacidade de o menino imaginar, inventar, faz com que a barreira fronteiriça seja transposta. O que evidencia uma inversão do estabelecido: o muro assegura o domínio, o status, mas não impede a capacidade inventiva, a transgressão.

Os muros tornaram-se símbolos de uma sociedade dividida em classes, lados, blocos, pólos antagônicos, gêneros em conflito. A eleição do espaço pantaneiro constitui o locus de enunciação da poética de Barros, sem, contudo, deixar de evidenciar questões urbanas, cosmopolitas, universais e atemporais. Em "O muro" (2004), parece que o eu poético vislumbra um mundo além dos muros. O pomar, enunciado entre parênteses, é o espaço fechado, o paraíso perdido de onde o poeta extrai a sua essência poética. Eis aí outra fronteira instaurada: os muros das urbes delimitam a poesia do lado de cá e o pomar (à parte) concretiza a poesia do lado de lá, a periférica. Ao investir no questionamento da separação real ou imaginária a que esse linde alude, observa-se o limite materializado entre o cosmopolita e o provinciano, o centro e a periferia. Desse modo, o muro assume não somente o sentido de defesa física do terreno, mas também do elemento que relativiza a alteridade. A identidade surge como algo ambíguo. No poema "O Muro", de Face Imóvel, a identidade surge inapreensível:

\section{O MURO}

Não possuía mais a pintura de outros tempos.

Era um muro ancião e tinha alma de gente.

Muito alto e firme, de uma mudez sombria.

Certas flores do chão subiam de suas bases

Procurando deitar raízes no seu corpo entregue ao tempo.

Nunca pude saber o que se escondia por detrás dele.

$[\ldots]$

(Barros, 2010, p. 40-41).

Nesse poema, o abandono social parece relacionar-se com o que havia por detrás desse muro. Há uma identificação com o espaço 
enunciado, mas há também uma assimetria entre o vivenciado e o narrado. O muro erige-se opaco, restritivo, sombrio, ainda que contenha a beleza que o tempo e as flores lhe emprestam. Além-muro o que existe só se pode supor, e o eu-lírico supõe que seja abandono. Se as andorinhas indiciam limite pela abstração, o muro de Face imóvel erigese na concretude, de bases firmes no chão onde deita raízes e a partir do qual ganha existência, e inapreensível identidade, como "alma de gente".

Ao que parece, o poeta percebe, no poema de 1942, os duros limites impostos pelas restrições com as quais o eu-lírico convive, para depois, no poema de 2004, desrealizar tais limites, erigindo-os pelo símbolo, pela metáfora das andorinhas. O outro lado, antes pressuposto, emerge como quintal que representa a urbe. É como se o poeta migrasse, de um muro ao outro, para a constatação de que as fronteiras se enraizaram pela padronização cosmopolita, cabendo ao poeta des-construir o sistema elitista do poder.

A relação com o espaço tem repercussões no processo de construção da identidade, a qual depende das relações dialógicas do eu com os outros. Ao tratar do conceito de fronteira, faz-se necessário refletir acerca da questão da identidade. Nas palavras de Stuart Hall:

A identidade [...] preenche o espaço entre o 'interior' e o 'exterior'entre o mundo pessoal e o mundo público. $\mathrm{O}$ fato de que projetamos a 'nós próprios' nessas identidades culturais, ao mesmo tempo que internalizamos seus significados e valores, tornando-os 'parte de nós', contribui para alinhar nossos sentimentos subjetivos com os lugares objetivos que ocupamos no mundo social e cultural. A identidade, então costura (ou, para usar uma metáfora médica, 'sutura') o sujeito à estrutura. (Hall, 2006, p. 12).

As identidades poéticas foram, parafraseando Hall, "suturadas" tanto pelo movimento de concentração e tradição quanto pela dispersão e expansão de ideias. Assim, cabe ao poeta que observa o mundo com olhos de menino deslocar padrões pré-estabelecidos. Nesse sentido, o discurso do reconhecimento aparece não só no âmbito individual, mas também na esfera pública.

A alteridade, apresentada no poema (2004) de Barros, mostra-se afastada da racionalidade do adulto e, conotativamente, identificada com o modo como a criança concebe e se relaciona com o meio que a cerca. Desse modo, o pomar, espaço almejado, "do outro lado do muro" (Barros, 2004, p. 59), é compartilhado no plano da imaginação. Há um 
obstáculo no caminho: o muro, responsável pela limitação do desejo; mas esse poema narrado em primeira pessoa torna-se, pois, como que um elogio à criatividade inventiva de quem traz o olhar infantil, o qual tem consciência da sua própria invenção: uma fronteira paradoxal, onde o impossível é possível. A fronteira surge, então, como um reino a ser desencantado: "Isso era" - e a forma verbal no pretérito imperfeito do indicativo faz lembrar a narração das fábulas, contos fantasiosos: "era".

A fronteira na poética barreana talvez seja um entre-lugar, resultante do que é concreto e do que é representação, com o qual o eu-lírico ora com ele se identifica, ora dele se afasta. É o limes que delineia dois campos, dois territórios, mas é o caminho, a estrada que o poeta precisa percorrer para perceber e manter sua identidade:

\section{[...] Esta estrada melhora muito} de eu ir sozinho nela. Eu ando por aqui desde pequeno. E sinto que ela bota sentido em mim. Eu acho que ela manja que eu fui para a escola e estou voltando agora para revê-la. Ela não tem indiferença pelo meu passado [...].

(Barros, 2003, XII).

Identidades refletem experiências históricas em comum e códigos culturais partilhados. Dessa forma, a estrada na poética barreana torna-se o limes, o trajeto que separa dois campos, a faixa que separa a diacronia, presente e pretérito, e os espaços, "aqui" e "a escola". A fronteira, então, nesse poema, significa um espaço de convivência da alteridade sem que esta seja um estrangeiro, ádvena.

No poema "O muro" (2004), não é o muro que faz a casa do menino diferente, mas a altura que a separa do pomar. A fronteira, assim, é um espaço definido por uma prática onde a alteridade inventa suas leis, é um terceiro espaço, o espaço do meio, é o "entre-lugar" (Santiago, 2000, p. 9) da interação, da complementaridade. O muro simboliza o limite demarcado entre dois territórios, mas relativiza a alteridade.

Segundo Silviano Santiago,

O escritor latino-americano brinca com os signos de um outro escritor, de uma outra obra. As palavras do outro têm a particularidade de se apresentarem como objetos que fascinam seus olhos, seus dedos, e a escritura do segundo texto é em parte a história de uma experiência sensual com o signo estrangeiro. (Santiago, 2000, p. 21). 
Os poemas "O muro", de Manoel de Barros, concretizam peculiar marco fronteiriço, como símbolo visível do limite de um espaço que não pertence a nenhum dos dois lados. A fronteira na poética barreana talvez seja um "entre-lugar", resultante do que é concreto e do que é representação, com o qual o eu-lírico ora com ele se identifica, ora dele se afasta. É o limes que delineia dois campos, dois territórios, mas é o caminho que o poeta precisa percorrer para perceber suas identidades. Parece-nos que os territórios, além de dominados, instrumentos de controle, de inclusão ou exclusão do diferente, são também apropriados, concreta e simbolicamente, numa infinidade de significados. Nesse sentido, o território é mutável de acordo com as forças sociais que nele operam; logo, é produto das relações de poder de quem constrói muros, de quem efetiva as faixas de fronteiras.

Examinemos agora essa fronteira que é limes e entre-lugar no âmbito das relações sociais tendo por foco a figurativização da mulher na poesia de Manoel de Barros. No dizer de Glaydson Silva, em seu estudo Representações Femininas e Relações de Gênero na Ars Amatoria,

Ao tratar do intercâmbio que se estabelece entre Literatura e História, ou, entre o texto literário e as percepções do 'real' nele expressas, torna-se imprescindível problematizar, ainda que brevemente, o uso que aqui se faz do conceito de representação, visto ser ele o instrumental analítico no qual se centra essa leitura. Duncan Kennedy ${ }^{3}$ concebe, acerca do termo, uma disjunção expressa entre arte e mundo, ou, literatura e vida. Para o autor, o termo está '[...] muito em evidência nas atuais discussões sobre a elegia amorosa romana' (1993, p. 1). Maria Wyke define a problemática em torno do discurso da representação como '[...] uma necessidade de determinar a relação entre a realidade da vida das mulheres e sua representação na literatura' (Cf. WYKE 1989, p. 25 apud KENNEDY 1993: 1) ela vê o realismo como uma qualidade própria do texto, '[...] não uma manifestação direta do mundo real' (p. 27). Para Roger Chartier as representações devem ser entendidas como '[...] representações que os grupos modelam deles próprios ou dos outros' (1991, p. 183). ${ }^{5}$ Sobre a atualidade destas discussões, Judith Hallet irá comentar que [...] debates sobre a mensagem ideológica da elegia latina e sua adequação para a pesquisa feminista prognosticam uma

${ }^{3}$ KENNEDY, Duncan F. The arts of love: Five studies in the discourse of Roman love elegy. New York: Cambrige University Press, 1993.

${ }^{4}$ Maria Wyke, citada por Kennedy, não é referenciada por Glaydson Silva.

5 CHARTIER, Roger. O mundo como representação. Estudos Avançados, São Paulo, v.r, n. 11, p. 180-193, jan./abr., 1991. cf. Glaydson Silva. 
satisfatória transformação dos estudos de literatura latina (1993, p. 64). ${ }^{6}$ Para a autora, estes debates conduzem para as várias formas de representação das mulheres na literatura do período; ainda que a elegia seja uma poesia dos meios sociais mais abastados, de um meio predominantemente aristocrático, com uma visão de mundo descrita dessa perspectiva (KENEDY, 1993. p. 1), as mulheres que nela aparecem - matronas, libertas ou escravas, ricas ou pobres são iguais em sua 'natureza'. (Silva, 2008, p. 2).

As representações femininas invocadas na poética de Manoel de Barros - aquelas que surgem como figuras pautadas nas virtudes do zelo pela harmonia do lar-, encenam personagens domesticadas e passivas, cujas condutas limitam a testemunhar sem intervir.

Perrot, em sua obra História da vida privada, faz a seguinte afirmação:

As relações cotidianas entre pais e filhos variam imensamente na cidade e no campo, onde as manifestações de ternura não são muito apreciadas, conforme os meios sociais, as tradições religiosas e mesmo políticas. A concepção que se tem da autoridade e da apresentação de sua própria pessoa influi sobre as palavras e os gestos do dia-a-dia. A família, desse ponto de vista, é o lugar onde se processa uma evolução contraditória. De um lado, o controle do corpo e da expressão emocional se aprofunda; isso se vê, por exemplo, na história das lágrimas, a partir de então reservadas às mulheres, às classes populares, à dor e à solidão, ou ainda na intensificação da disciplina sobre a linguagem e as atitudes físicas das crianças, intimidadas a ficar retas, a comer direito, e assim por diante. De outro lado, a troca de carinhos entre pais e filhos é tolerada, e até desejada, pelo menos na família burguesa. (Perrot, 1991, p. 157).

Cabe-nos observar que a década de 1930 - não será demais lembrar, momento em que Barros publicou sua primeira obra, PCSP - foi um período de muitas conquistas da mulher. Acerca dessa questão, Carlos Martins Júnior, no artigo "O esforço de construção de representações femininas idealizadas nos jornais mato-grossenses no Estado Novo", assim anota:

\footnotetext{
${ }^{6}$ HALLET, Judith. Feminist Theory, Historical periods, literary cannos, and the study of Greco-Roman antiqquity. In: RABINOWITZ, Nancy Sorkin, RICHLIN, Amy. (Orgs.). Feminist theory and the classics. New York: Routledge, 1993. p. 44-72.
} 
Pouco a pouco, as conquistas femininas no exterior repercutiam no Brasil, com o próprio Governo Provisório acatando algumas de suas reivindicações. Em 1932, durante as eleições para a Assembléia Constituinte, foi concedido o direito de voto às mulheres. $\mathrm{Na}$ Constituição de 1934, a participação feminina na política se acentuou e vários artigos da Constituição viriam a beneficiá-las, a exemplo da regulamentação do trabalho feminino já previsto nos Decretos Leis de 17 de maio de 1932. (Martins Júnior, 2006, p. 117-133).

Samara, em seu estudo, intitulado Mulheres pioneiras: histórias de vida na expansão do povoamento paulista, acrescenta:

Para as historiadoras dedicadas ao estudo da condição feminina no passado, essa questão aparece logo de início como um desafio, ou mesmo um desejo de recuperar as mulheres na sua identidade social e de mostrar sua presença no processo de tomada de decisões. Vejam-se, por exemplo, os trabalhos de Susan Rogers sobre o mito da dominação masculina e os 'poderes' femininos e de Michelle Perrot sobre a mulher popular rebelde, entre muitos outros. (Samara, 2002, p. 19).

Na obra Memórias inventadas: a infância (2003), no poema intitulado "Fraseador", Barros descreve uma cena no espaço privado do domus $^{7}$ em que a figura da mãe é personificada como coadjuvante:

Hoje eu completei oitenta e cinco anos. O poeta nasceu de treze. Naquela ocasião escrevi uma carta aos meus pais, que moravam na fazenda, contando que eu já decidira o que queria ser no futuro.

Que eu não queria ser doutor. Nem doutor de curar nem doutor de fazer casa nem doutor de medir terras. Que eu queria era ser fraseador. Meu pai ficou meio vago depois de ler a carta. Minha mãe inclinou a cabeça. Eu queria ser fraseador e não doutor. Então, o meu irmão mais velho perguntou: Mas esse tal de fraseador bota mantimento em casa?

Eu não queria ser doutor, eu só queria ser fraseador. Meu irmão insistiu:

Mas se fraseador não bota mantimento em casa, nós temos que botar uma enxada na mão desse menino pra ele deixar de variar. A mãe baixou a cabeça um pouco mais. O pai continuou meio vago. Mas não botou enxada.

(Barros, 2003, VII).

\footnotetext{
7 Acrescentemos aqui, apenas como uma observação à margem, a asserção de Kant, que dizia que a casa, o domicílio, que encerra em suas paredes tudo o que a humanidade recolhe ao longo dos séculos, é a única barreira contra o horror do caos, da noite e da origem obscura.
} 
Estão associados, ao vocábulo "mãe", os verbos "inclinar" e "baixar", os quais podem conotar vários sentidos: desânimo, decepção, cansaço, alheamento, submissão, resignação ou compreensão e tolerância diante da decisão do filho "fraseador". Entretanto, parece-nos que ao empregar os verbos "inclinar" e "baixar", associados ao sujeito verbal "A mãe", o poeta, nesse poema, apresenta a mulher como coadjuvante nas decisões familiares, pois o filho mais velho questiona, até mesmo sugere uma atitude, quase que um castigo: "nós temos que botar / uma enxada na mão desse menino pra ele deixar de variar." O pai, no entanto, deixa a questão para lá, "meio vago", e à mãe cabe tão somente "baixar a cabeça um pouco mais" - no domus, à mulher cabe a submissão.

O eu-lírico informa ao leitor que a cena rememorada ocorrera há mais de setenta anos ("Hoje eu completei oitenta e cinco anos. O poeta nasceu de treze"). Há, no poema, outros índices que merecem destaque: a prática epistolar era própria de pessoas alfabetizadas, com facilidade de redigir, e talvez represente um indício da vocação de escritor reiterada pelo eu enunciador. Conforme muitos historiadores, ${ }^{8}$ o domínio da escrita, na zona rural, era quase que exclusividade dos homens.

Embora sejam poucos os elementos físicos e morais fornecidos pelo poema ao leitor, esses são suficientes para configurar o perfil feminino, de forma impressiva, no universo familiar descrito por Barros. A figura representada, no poema, é a da mulher no universo patriarcal rural; ela, na sua passividade e impotência, tenta ocultar suas emoções, o que transparece no gesto de "baixar a cabeça". A seleção vocabular transforma o gesto único em exemplo da circunstância a que estava submetida a figura feminina.

No poema "Fraseador", existem duas histórias: uma individual e outra coletiva. ${ }^{9}$ A individual recupera as reminiscências do poetanarrador cuja família, à época em que ele estudava no colégio, interno, no Rio de Janeiro (Barros, 2003, IV), morava na fazenda (Barros, 2003, VII) e com a qual se correspondia, provavelmente, através de cartas. A história coletiva presente no poema é gerida pelas questões políticas e sociais do País no que tange às discussões acerca das conquistas femininas nesse período. Descreve-se uma cena familiar comum, mas ao que nos parece - subjaz no poema narrado um engajamento ideológico acerca da condição da mulher na família patriarcal rural.

\footnotetext{
8 A informação é tão disseminada que se torna ocioso referendá-la com alguma abonação.

9 Não se trata, aqui, do conceito de Píglia (1994), de que "um conto sempre conta duas histórias".
} 
Em outros poemas de Barros, a figura feminina surge como "transgressora", é o protótipo familiar liberal, ainda que não promova transformações na realidade vigente. Essa representação emerge com as mulheres mais experientes, como a "avó", "Nhanhá". Apesar de reações socialmente consideradas como típicas do universo feminino, tais como o choro, a preocupação com os familiares e o cuidado com a educação das crianças, é a avó que orienta o eu-lírico a infringir certos padrões e conceitos. Esse espírito libertário surge tanto nos Poemas Concebidos sem Pecado quanto nas Memórias inventadas: a infância.

Nhanhá, a avó que educa e orienta, surge em "Cabeludinho" $(P C S P)$ :

- Vai desremelar esse olho, menino!

- Vai cortar esse cabelão, menino!

Eram os gritos de Nhanhá.

(Barros, 2005, p. 9).

Ela se entristece com a partida do neto:

$[\ldots]$

Havia no casarão umas velhas consolando Nhanhá que chorava feito uma desmanchada

- Ele há de voltar ajuizado

- Home-de-bem, se Deus quiser

(Barros, 2005, p. 17).

A avó é o membro familiar com quem o eu-lírico parece se identificar, o que depreendemos dos versos seguintes, em que o adolescente racionaliza sua rebeldia:

Carta acróstica:

"Vovó aqui é Tristão

Ou fujo do colégio

Viro poeta

Ou mando os padres..."

Nota: Se resolver pela segunda, mande dinheiro para comprar um dicionário de rimas e um tratado de versificação de Olavo Bilac e Guima, o do lenço.

(Barros, 2005, p. 21). 
Quando descobre que "o neto que foi estudar no Rio [...] voltou de ateu” (Barros, 2003, VIII), é a avó aquela que mais sofre:

$[\ldots]$

Nhanhá choraminga:

- Tá perdido, diz que negro é igual com branco!”

(Barros, 2005, p. 31).

Ao mesmo tempo, é a avó, no poema “Obrar”, que inspira o narrador a ser um "transgressor" e "a não desprezar as coisas desprezíveis e nem os seres desprezados":

$[\ldots]$

A vó então quis aproveitar o feito para ensinar que o cago não é uma coisa desprezível.

Eu tinha vontade de rir porque a vó contrariava os ensinos do pai.

Minha avó, ela era transgressora.

(Barros, 2003, II).

A mulher mais velha, na obra de Barros, parece representar os atributos femininos de "choramingar", ensinar as crianças, mas com uma singularidade: a de desempenhar também a função paterna na disciplina dos filhos. Nos intertíscios do patriarcado, ou ainda mais o firmando, dá lições de transgressão ao eu-lírico masculino, alter-ego do poeta.

Se, por um lado, à mãe cabe "baixar a cabeça", à avó, a mulher mais velha, cabe a orientação e des-orientação quanto às condutas sociais. Mas, não deixa de ser também bastante significativo observar o olhar de quem as recria. Nessa perspectiva, em um aparente paradoxo, o eu-enunciador que "vai desremelar o olho", reconhece também sua masculinidade ao perceber que "a vó contrariava os ensinamentos do pai" e o orienta, ao menino, a não aceitar o pré-estabelecido.

Em sua Poética, Aristóteles argumenta que a poesia contém um teor mais filosófico do que o discurso histórico, pois narra imaginativamente o que poderia ter ocorrido e não se atém a um relato pretensamente fidedigno dos acontecimentos.

Barros, em entrevista a José Castello (1997), indicia que, em sua poesia, retoma fatos da realidade e os recria poeticamente. Assim se dá no poema "Maria-pelego-preto", personagem recriada a partir de uma realidade de miséria que o poeta presenciou: 
Estado - E o que encontraram pelo caminho?

Manoel - Miséria. Em Santa Cruz de la Sierra, fomos abordados por um menino que veio oferecer-nos mulher. Ele nos levou a uma casa muito pobre e nos apresentou a suas três irmãs, três meninas miseráveis. O menino pegava homens na rua para transar com as irmãs, era assim que a família sobrevivia. Essa experiência rendeume um poema, que chamei de Maria-Pelego-Preto.

Estado - Ela existiu mesmo?

Manoel - Sim, uma das meninas tinha pentelhos que subiam até o umbigo. Os pais exploravam esses pêlos como um fenômeno, uma anormalidade. Cobravam ingressos só para exibi-los. (Castello, 1997).

Sob esta perspectiva, a obra de Manoel de Barros constitui objeto de análises para os estudos fronteiriços, visto que há em sua poesia significativas reflexões acerca de fatos que ocorrem num tempo e num espaço peculiares, fatos que repercutem por meio da "voz" do eu-lírico. Na obra A mulher na história do Brasil, Del Priore assim relata:

A prostituição, embora aparentemente transgressora, constituíase numa prática a serviço da ordem sócio-espiritual no mundo moderno. No Brasil, no entanto, as características que a tornavam um 'mal necessário', vão misturar-se com outras práticas consideradas pelas autoridades como transgressoras, fazendo com que a igreja enxergasse em cada mulher que infringisse as normas, uma prostituta em potencial. Como não se isolava as prostitutas em 'putarias e mancebias', nem se as cobria com véus como era uso na metrópole, na colônia os limites entre os comportamentos tidos por desviantes e a prostituição eram tênues. (Del Priore, 1994, p. 22).

Em PCSP, a personagem Maria-pelego-preto é assim poetizada:

\section{Maria-pelego-preto}

Maria-pelego-preto, moça de 18 anos, era abundante de pêlos no pente.

A gente pagava pra ver o fenômeno.

A moça cobria o rosto com um lençol branco e deixava pra fora só o pelego preto que se espalhava quase até pra cima do umbigo.

Era uma romaria chimite!

Na porta o pai entrevado recebendo as entradas...

Um senhor respeitável disse que aquilo era uma

indignidade e um desrespeito às instituições da família e da

Pátria!

Mas parece que era fome.

(Barros, 2005, p. 51). 
Não se expressa, nesse poema, apenas a representação de uma realidade nem pretende o poeta somente instaurar a comoção do leitor. Ao que parece, há uma voz, a do narrador, que denuncia a exploração da mulher, da pessoa humana, em nome da miséria, da fome como justificativa para o sustento da família na sociedade capitalista. ${ }^{10}$

Maria-pelego-preto é encarada com certa simpatia pelo eu enunciador, pois esta é apresentada como vítima de um sistema em que o diferente torna-se fenômeno, aberração, em que a mulher é subjugada ao poder patriarcal. Nessas poucas referências fornecidas pelo narrador, todo um conjunto de valores se constela: o físico, o moral, a ética da prestação de serviço, do trabalho ("o pai entrevado recebendo as entradas") e a dinâmica da relação social em que um homem se relaciona com outros, às vezes de diferente condição socioeconômica, visando exclusivamente aos seus prazeres. No que diz respeito à ética do trabalho, o narrador chama-nos a atenção ("mas parece que era fome"), deixando que o leitor faça seus julgamentos e tire as suas conclusões.

Nesse sentido, o poeta, ao apresentar o que, parece, já se banalizou, tornou-se comum na sociedade, "A gente pagava pra ver o fenômeno", atenta para a reflexão, a tomada de consciência do leitor, revelando uma sociedade fragmentada, em que o "pentelho", os pêlos pubianos da "moça de 18 anos", torna-se um bem consumível mais significativo que o ser.

Entre o captado pelo olhar do poeta e a realidade vigente, ao que nos parece, a casa - guardada pelo "pai entrevado" - é um microcosmo percorrido por fronteiras para as quais convergem, e nas quais se confrontam o privado e o público: o sexo está na cotação; o íntimo é revelado, mas o rosto fica encoberto pelo lençol branco, talvez uma alusão simbólica à justiça: olhos vedados.

O poeta não se isentou de apresentar, nesse poema, uma sociedade que sujeita a mulher ao papel de coadjuvante e que muitas vezes a personifica como "pecadora", faz dela um objeto de compra e venda. Os homens, em bando, se satisfazem em "avaliar" a mercadoria: "Era uma romaria chimite!"

Outra personagem feminina da obra de Barros que parece refletir o modo como a sociedade patriarcal caracteriza a mulher é Antoninhame-leva:

\footnotetext{
${ }^{10}$ No Brasil, a condição da mulher na literatura - seja como objeto de representação, como autora ou como leitora - começou a ser objeto de estudos acadêmicos somente no final dos anos sessenta; e esse poema é dos anos trinta.
} 


\section{Antoninha-me leva}

Outro caso é o de Antoninha-me-leva:

Mora num rancho no meio do mato e à noite recebe os vaqueiros tem vez que de três e até quatro comitivas

Ela sozinha!

Um dia a preta Bonifácia quis ajudá-la e morreu.

Foi enterrada no terreiro com o seu casaco de flores.

Nessa noite Antoninha folgou.

Há muitas maneiras de viver mas essa de Antoninha era de morte! Não é sectarismo, titio.

Também se é comido pelas traças, como os vestidos.

A fome não é invenção de comunistas, titio.

Experimente receber três e até quatro comitivas de boiadeiros por dia!

(Barros, 2005, p. 73).

A mulher representada nesse poema é a prostituta. Sob a ótica do eu-enunciador, trata-se de uma mulher que mora num lugar pobre e distante do mundo civilizado, "num rancho no meio do mato". Seu comportamento zoomorfizado parece condizente com o meio. $\mathrm{O}$ vigor e a resistência física da personagem fogem aos padrões das demais mulheres: "Um dia a preta Bonifácia quis ajudá-la e morreu". Ao que parece, há uma tomada de posição do narrador, que não compactua com a ideologia vigente na sociedade da época, o que fica indiciado pelo verbo "experimentar" do último verso do poema. E o verbo, na ambiguidade entre o subjuntivo e o imperativo, lança um desafio, pois que a atividade de Antoninha se mostra grandiosa, quase épica no seu heroísmo.

Essa quase virilidade de Antoninha-me-leva, sua resistência física, revela-nos que, de certa maneira, essa personagem ganha a simpatia do narrador. Por outras palavras, o narrador se converte em um portavoz dos sentimentos de Antoninha, como nos versos finais do poema citado. O poema simula um diálogo em que o tio representa a voz social discriminadora, a voz do eu-poético enuncia solidariedade, com a qual o eu-lírico utopicamente se irmana, como que dando voz para que a própria Antoninha manifeste suas dores.

De acordo com a obra A mulher na História do Brasil, de Del Priore,

[...] Deslocadas dos bordéis, como se usava na Europa, e à mercê dos casamentos instáveis consagrados pelas condições de vida do período, compreendemos melhor as prostitutas sob o pano de fundo da pobreza, onde o meretrício era um ofício ou uma forma de trabalho, ligada à mais imediata sobrevivência. (Del Priore, 1994, p. 26). 
Em seus poemas, compostos de forma narrativizada (cf. GráciaRodrigues, 2006), Barros representa as mulheres do povo geralmente na cozinha ou próximas aos afazeres domésticos. Em PCSP:

$[\ldots]$

Um dia Nhanhá Gertrudes fazia bolo de arroz

Negra Margarida socava pilão.

E eu nem sei o que fazia mesmo.

Veio um negro risonho e disse sem perder o riso:

- Vãobora comigo negra?

(Barros, 2005, p. 40).

As mulheres do povo surgem representadas também em momentos em que contam histórias, como no poema "Achadouros", da obra Memórias Inventadas: a infância:

[...] Aquilo que a negra Pombada, remanescente de escravos do Recife, nos contava. Pombada contava aos meninos de Corumbá sobre achadouros.

(Barros, 2003, XIV, sublinhado no original).

Surgem, ainda, as mulheres, queixando-se das suas condições. Em PCSP, a personagem Dona Maria representa as mulheres que buscam libertar-se de condições não explicitadas. É mais um poema narrativizado:

\section{Dona Maria}

Dona Maria me disse: não agüento mais, já tô pra comprar uma gaita, me sentar na calçada, e ficar tocando, tocando...

- Mas só pra distrair?

- Que Mané pra distrair! O senhor não está entendendo?

- Entendo. A senhora vai ficar sentada na calçada, de vestido sujo, cabelos despenteados, esquálida, a soprar uma gaitinha rouca, não é?

$[\ldots]$

(Barros, 2005, p. 53).

De acordo com Del Priore (1994, p. 27), “[n]as cidades coloniais, as 'mal procedidas' ganham suas vidas em praças, fontes, ruas e casas de comércio, até esbarrar na repressão periódica de autoridades ou da vizinhança, incomodados com suas brigas e ameaças". 
O nome Maria congrega vários sentidos e pertence a várias histórias, sacras ou profanas, e representa o feminino real ou inventado. Na obra de Barros, ora surge subjugada ao regime patriarcal, "Na porta o pai entrevado recebendo as entradas...", ora representa a mulher, nem casta nem obediente, mas que clama pela liberdade em relação às convenções sociais, que muitas vezes propõe como realização plena da condição feminina a dedicação exclusiva à vida do lar: "não agüento mais, já tô pra/ comprar uma gaita, me sentar na calçada, e ficar tocando, / tocando".

Permite-nos aprofundar a análise, no aspecto em que empreendemos nossa leitura, o estudo A unidade dual: Manoel de Barros e a poesia, de Prioste:

$\mathrm{O}$ poeta reconhece o fingimento da palavra e apreende a realidade como um cenário construído a partir do alicerce verbal. Percebe que a fronteira com o falseio é muito tênue para ousar referendar um discurso que se pretende claro e distinto quando tudo é muito mais complexo e indefinível do que supõe qualquer filosofia. A obscuridade compartilha da clareza em um infinito enlace no qual o humano se embate sem a certidão fidedigna de uma verdade imune ao contradito, ao dubitável e ao oblíquo. (Prioste, 2006 p. 19).

A opção pelos marginalizados é uma tônica constante na poética de Manoel de Barros. Ao narrar as histórias dessas personagens femininas, o poeta revela-nos várias fronteiras construídas no espaço e no tempo. A realidade da concretude histórica é apreendida como discurso, é discurso. Assim, torna-se esquiva, indefinível, obscura; torna-se complexa e permeada pelas dúvidas inerentes à linguagem, ao discurso construído, ao ideológico que emerge na ontologia da língua.

É a necessidade de expor o real, o concreto, transfigurando-o poeticamente, que singulariza a poesia de Manoel de Barros, não apenas como homem e como artista, mas porque sua obra não se prende à descrição de situações sociais injustas, o que o afasta da mediocrização da sondagem social rasa. A poesia barreana aproxima o factual do ficcional, do poético, tendo um veio subterrâneo de compaixão, humanismo e leitura do fato social.

$\mathrm{O}$ eu-enunciador cede a palavra à personagem $\mathrm{D}$. Maria não como registro exterior, mas como manifestação do seu íntimo humano ("não aguento mais...").

E assim, o eu-lírico se volta para as lembranças recuperadas, tornando-as memórias que se expressam nos poemas narrativizados de 
PCSP e de todos os volumes das Memórias inventadas. No recorte que observamos e descrevemos, a evocação poética se fixa sobre as figuras femininas, tanto as do domus quanto aquelas expostas nas ruas.

Nesse momento, as figuras singulares do poeta como que representam todas as milhares de mulheres da América Latina que viveram e vivem no atraso, na pobreza e nos ermos da solidão (a lembrança mais forte aqui é a personagem Ana Terra, de Érico Veríssimo). Ainda hoje elas são vendidas como escravas, são mutiladas, são torturadas e são prostituídas. A independência econômica é conquista evidenciada, principalmente, nos grupos privilegiados das zonas urbanas. Entre a autonomia e a heteronomia, muitas são as fronteiras sociais que prendem a mulher à subalternidade, em prolongamento de situações que o poeta descrevia nos anos trinta do século XX. Tal fronteira social tem deixado lacunas que merecem estudos mais aprofundados. Apesar dos recentes embates acerca dessa questão, o problema do tráfico humano e o da exploração sexual feminina são constantes nos veículos midiáticos quando se referem ao Brasil.

Com efeito, as personagens femininas da obra de Barros protagonizam uma humanidade fragmentada pelo sexismo, pelo poder simbólico (cf. conceito elaborado por Bordieu, 2007) instituído em nome dos costumes e das criações culturais. E ao revelar poeticamente o outro silenciado, marginalizado, o poeta descortina o real, o concreto, sem se prender a descrições emocionadas de situações sociais ou panfletos políticos.

A produção literária de Manoel de Barros, entre outros aspectos, é também expressão das emoções e reflexões do poeta diante do mundo, da defesa da poesia como fundamento do humano e de crítica ao sexismo, à miséria, à exclusão e à diferença entre gêneros. A identidade que exclui, que se ergue como fronteira ou muro, tem por contraponto a concepção de que entre o eu e a alteridade há um entrelugar que deve ser limes, espaço de encontro, de trânsito.

A obra de Barros tem como efeito - para além do estético ou de qualquer compromisso político - clamar pela humanização em um mundo no qual impera a mecanização, a reificação, a coisificação do ser como objeto de consumo e alienação. É arte que recusa o condicionamento do meio; é, por isso, transgressora e revolucionária. As fronteiras internas, na sociedade vincada por diferenças gritantes de renda, de escolaridade, de acesso a bens culturais, constituem fronteiras entre culturas distintas em que o outro, diferente em sua alteridade, torna-se um estranho absoluto; tais fronteiras, construídas ao longo da História, presentificam- 
se na poesia de Manoel de Barros quando a estudamos sob o enfoque da representação mimética da figura feminina, como empatia ao espoliado e como denúncia da estrutura econômico-social que gera tal situação. A revolução da forma e da linguagem que é estesia clama por revoluções outras, que poetizem o dia-a-dia e modifiquem a relação dos homens entre si e com os objetos.

\section{Referências}

ARISTÓTELES. Poética. Trad. Eudoro de Souza. São Paulo: Abril, 1973. (Os pensadores, IV).

BARROS, Manoel. Poemas concebidos sem pecado. 4. ed. Rio de Janeiro: Record, 1999. $78 \mathrm{p}$.

BARROS, Manoel. Memórias inventadas: a infância. São Paulo: Planeta, 2003. XV cadernos.

BARROS, Manoel de. Poemas rupestres. Rio de Janeiro: Record, 2004. 75 p.

BARROS. Poesia completa. São Paulo: Leya, 2010. 493 p.

BOURDIEU, Pierre. O poder simbólico. Trad. Fernando Tomaz. 11. ed. Rio de Janeiro: Bertrand Brasil, 2007. 322 p.

CASTELlO, José. Manoel de Barros faz do absurdo sensatez. O Estado de S. Paulo, 18 out. 1997. Caderno 2, p. 1-3. Reproduzido em: <http://www.jornaldepoesia.jor.br/ castel11.html>. Acesso em: 9 set. 2011.

DEL PRIORI, Mary. A mulher na história do Brasil. 4. ed. São Paulo: Contexto, 1994. 64 p. (Coleção Repensando a história).

GRÁCIA-RODRIGUES, Kelcilene. De corixos e de veredas: a alegada similitude entre as poéticas de Manoel de Barros e de Guimarães Rosa. 312 f. Tese (Doutorado em Estudos Literários) - FCL-Ar, UNESP, Araraquara, 2006.

HALL, Stuart. A identidade cultural na pós-modernidade. Trad. Tomaz Tadeu da Silva, Guaracira Lopes Louro. 11. ed. Rio de Janeiro: DP\&A, 2006. 102 p.

MARTINS JÚNIOR, Carlos; TRUBILIANO, Carlos Alexandre Barros. O esforço de construção de representações femininas idealizadas nos jornais mato-grossenses no Estado Novo. In: BORGES, Maria Celma; OLIVEIRA, Vitor Wagner Neto de (Orgs.). Cultura, trabalho e memória: faces da pesquisa em Mato Grosso do Sul. Campo Grande: UFMS, 2006. p. 117-133.

MURARO, Rose Marie. Sexualidade da mulher brasileira - corpo e classe social no Brasil. 3. ed. Petrópolis, RJ: Vozes, 1983. 501 p.

PERROT, Michellle. História da vida privada 4: da Revolução Francesa à Primeira Guerra. Trad. Bernardo Joffily. São Paulo: Companhia das Letras, 1991. 637 p.

PIGLIA, Ricardo. Teses sobre o conto. In: PIGLIA, Ricardo. O laboratório do escritor. Trad. Josely Vianna Baptista. São Paulo: Iluminuras, 1994. p. 37-41.

PRIOSTE, José Carlos Pinheiro. A unidade dual: (Manoel de Barros e a poesia). Tese (Doutorado em Ciência da Literatura) - Faculdade de Letras, Universidade Federal do Rio de Janeiro, Rio de Janeiro, 2006. 
RAFFESTIN, C. Por uma geografia do poder. São Paulo: Ática, 2005.

SAMARA, Eni de Mesquita. Histórias de vida na expansão do povoamento paulista. BRASA VI-International Congress - Brazil: new visions. 2002. Disponível em: $<\mathrm{http}: / /$ sitemason.vanderbilt.edu/files/etVaU0/Samara\%20Eni\%20de\%20Mesquita.pdf $>$. Acesso em: 3/10/ 2011.

SANTIAGO, Silviano. Uma literatura nos trópicos: ensaios sobre dependência cultural. Rio de Janeiro: Rocco, 2000. 219 p.

SILVA, Glaydson José da Silva. Representações femininas e relações de gênero na Ars Amatoria. Disponível em: <http://www.gtantiga.net/textos/textosbeccpa.pdf $>$. Acesso em: 3 out. 2011.

VERÍSSIMO, Érico. Ana Terra. São Paulo: Companhia das Letras, 2005. (Integra o ciclo O tempo e o vento). 